\title{
Examining the Impact of Lean Practices on Flexibility Performance: The Moderating Effect of Environmental Dynamism
}

\author{
Zu'bi M. F. Al-Zu'bi ${ }^{1}$ \\ ${ }^{1}$ Department of Business Management, Faculty of Business, The University of Jordan, Jordan \\ Correspondence: Zu’bi M. F. Al-Zu'bi, Department of Business Management, Faculty of Business, The \\ University of Jordan, Amman, ON., 11942, Jordan. Tel: 962-79-562-9397. E-mail: zoz55jo@yahoo.com
}

Received: September 10, 2015

Accepted: October 8, $2015 \quad$ Online Published: October 15, 2015

doi:10.5539/emr.v4n2p54

URL: http://dx.doi.org/10.5539/emr.v4n2p54

\begin{abstract}
This paper examined the effects of four core and internal lean practices on flexibility performance in Jordanian manufacturing companies. Lean practices included setup time reduction, continuous improvement, synchronization of operations, and pull system. A survey questionnaire was used to collect data from 157 manufacturing companies from different industry types. Hierarchical regression analysis showed that lean production posively and significantly affected flexibility performance. All lean practices proved to be positively and significantly related to flexibility performance. The most contributing lean practice was synchronization of operations followed by pull system and continuous improvement. The moderating effect of environmental dynamism was also examined. The results of the interaction terms showed that environmental dynamism positively and significantly moderated the relationship between synchronization of operations and flexibility performance. The findings of this study highlighted the important role of synchronization of operations, a widely neglected lean practice in the literature, in improving flexibility performance. Additionally, we contributed to the controversial issue in the literature concerning the impact of lean production on performance in a dynamic environment.
\end{abstract}

Keywords: lean production, lean practices, flexibility performance, environmental dynamism, moderating effect, synchronization of operations, Jordan, empirical study

\section{Introduction}

The last three decades witnessed a series of new operational approaches that attemted to improve quality, reduce cost, enhance productivity, and improve competitive position of manfufacturing companies. Such approaches included, but not limited to, total quality management, just in time production, total productive maintenance, and lean production. Although those approaches were initiated in Japan, they received a considerable attention by manufacturing companies in Western contries. As for developing countries, total quality management still the most popular and well known Japanese management approach. The other operational approaches started getting popularity in developing countries in the last years (Abdallah, 2013). The severe competitive situation that shifted towards a global basis has forced many manufacturing companies in the developing contries to adopt innovative operational practices to remain competitive. Some of the factors that led to such a competitive situation include globalization, free trade agreements, and World Trade Organization (WTO) membership.

Jordan is a country that suffers a lack of natural and economic resources. Manufacturing companies in Jordan have been struggling due to several reasons. Such reasons include the unrecovered effects of the 2008 global economic crisis, free trade agreements, membership in the WTO, and instability in the Middle East. Lean production has been regarded as an ideal response to the current challenges that Jordanian manufacturers face, so that to remain competitive in the local market and to attempt to compete in the regional and global markets. Lean production focuses on improving process efficiency and effectiveness, which were referred to as the most important benefits of lean production (Ohno, 1988; Womack et al., 1990; Liker, 2004). A successful process strategy should be evaluated based on company's flexibility to respond to business and market changes (Abdallah \& Matsui, 2007b; Abdallah et al., 2009).

Published literature demonstrated various benefits of lean production including waste elimination, cost reduction, performance improvement, quality improvements, inventory reduction, lead time reduction, and productivity improvements (Abdallah \& Matsui, 2007a; Phan et al., 2011; Abdallah, 2013; Al Hasan \& Al-Zu'bi, 2014). 
Previous research investigated the relationship between lean production and different aspects of performance such as operational, financial, and employee performance. However, we noted that there is a lack of research papers that investigated lean production in developing countries in general and in Jordan in particular. Additionally, there is an apparent gap in the literature concerning the explicit linkages between lean practices and flexibility performance. We failed to find any research paper that investigated this relationship in Jordan or other developing countries. Moreover, this study contributes to the literature by assessing the moderating effect of environmental dynamism, by which the current business environment is characterized. Investigating moderating effects is critical to assess the impact of lean practices on performance (Danese et al., 2012). Mackelprang and Nair (2010) asserted that such interactions may potentially contribute to advance theory with regard to lean system and may explain the contrasting findings reported in the literature. They argued that about 50 percent of the relations between lean practices and performance are subject to interaction effects.

This study attempts to fill the gaps in the literature by investigating the discussed effects. Data was collected from 157 manufacturing companies in Jordan. The research questions are:

1) What are the effects of lean practices on flexibility performance in Jordanian manufacturing companies?

2) What is the moderating effect of environmental dynamism on the relationship between lean practices and flexibility performance in Jordanian manufacturing companies?

The findings of this study are expected to contribute to the current lean literature by exploring lean practices that affect flexibility performance. Additionally, lean-flexibility relationship has not been investigated previously under environmental dynamism. The results are expected to contribute to the literature from both theoretical and practical perspectives.

\section{Literature Review and Theoretical Background}

\subsection{Lean Production}

The term "Lean" was introduced by Womack et al. (1990) in their classical book "The Machine that Changed the World". The book highlighted Japanese production system in general, and Toyota production system in particular compared to traditional mass production. They selected the term "Lean" to describe Toyota production system because this system uses half resources compared with mass production, such as half working hours, half manufacturing space, and half investment in equipment. One main difference between mass production and lean production lies on their ultimate goals. The goal of mass producers is to be "good enough" which could be translated as acceptable number of defects, inventories, and narrow standardization. The goal of lean producers is perfection which means declining costs, almost zero defects and inventories, and more product variety (Womack et al., 1990). Shah and Ward (2007) defined lean production as: "An integrated socio-technical system whose main objective is to eliminate waste by concurrently reducing or minimizing supplier, customer, and internal variability". Papadopoulou and Ozbayrak (2005) defined lean as "an approach to manufacturing that is aimed at the elimination of waste while stressing the need for continuous improvement", while Worley and Doolen (2006) defined it as "a systematic removal of waste by all members of the organization from all areas of the value stream".

Womack and Jones (2003) pointed to five principles as major lean principles which included value, the value stream, pull, flow, and perfection. Cost and Rothenberg (2004) viewed lean elements in terms of just in time, continuous improvement/Kaizen and Human Resource policies. Shah and Ward (2003) identified 22 lean practices and categorized them into four bundles, total quality management, just-in-time, human resource management, and total productive maintenance. Abdallah and Matsui (2009) investigated lean manufacturing in terms of just in time production, total quality management, human resource management, total productive maintenanace, supplier relationship management, customer relationship management, and manufacturing strategy. Detty and Yingling (2000) pointed to eight lean principles which included level production, process stability, standardized work, visual control, just in time, quality, continuous improvement and production stop procedure. Sanchez and Perez (2001) proposed six groups of lean manufacturing which included continuous improvement, elimination of zero-value activities, just in time production and delivery, multifunctional teams, integration of suppliers, and flexible information system. Taj and Morosan (2011) reported three lean operations practices which included human resources, supply chain, and product system design. Agus and Hajinoor (2012) measured lean manufacturing in Malaysia in terms of set up time reduction, continuous improvement, pull production, short lead times, and small lot size. It can be noticed that researchers used different practices and dimensions to describe and measure lean production. Despite lean production is a hot research topic, there is still no consensus on a specific definition of it or on underlying practices related to its implementation (Jain \& Lyons, 2009; Abdallah \& Matsui, 2009). 
In order to identify lean practices in this study, only core and internal lean practices were considered. We identified the most cited practices in the literature and selected the following four lean practices: setup time reduction, continuous improvement, synchronization of operations, and pull system (Flynn et al., 1997; Sakakibara et al., 1997; Phan \& Matsui, 2006; Ahmad et al., 2003; Shah \& Ward, 2007; Abdallah \& Phan, 2007; Al-Zu'bi et al., 2012; Agus \& Hajinoor, 2012; Abdallah et al., 2014). Those practices encompass the main elements of core and internal lean practices such as just in time production which is reflected by pull system, total quality management which is reflected by continuous improvement. Setup time reduction and synchronization of operations have been widely referred to as core lean practices. As the focus of this research is on internal core lean practices, lean practices along the supply chain such as supplier involvement were out of the scope of this study. Similarly, lean human resource practices were not considered in the current study. The four lean practices adopted in this research will be discussed in the following sub-sections.

\subsubsection{Setup Time Reduction}

Setup time is defined as the time between the last acceptable unit of the previous run to the first acceptable unit of next run (Shingo, 1985). Toyota lean system succeeded due to its ability to reduce setup times, which was considered as a major non-value adding activity. Setup time reduction is regarded as the focal point for manufacturing companies to improve their flexibility. Among the proposed approaches in the literature to reduce setup time, Single Minute Exchange of Die (SMED) and the 5S activities are the most prominent (Womack et al., 1990). 5S activities include separation, sorting, shine, standardizing, and sustaining. The idea of $5 \mathrm{~S}$ is simple and requires re-organizing the work place so that component and machines are located close to the operator in order to eliminate time spent in locating the required components (Imai, 1986). SMED is a set of procedures originally initiated to improve die press and machine tool change over and later was adopted by different manufacturing companies and processes to reduce set up time in less than 10 minutes (Shingo, 1985).

Albert (2004) emphasized the role of setup time reduction in increasing flexibility of lean plants. He proposed a step by step approach for applying setup time reduction and translating it into efficient and lean manufacturing. By reducing setup time, companies will be able to minimize inventory levels which will be reflected in considerable cost savings, processes will become more productive and flexible resulting in improved responsiveness (Al-Zu'bi, 2010; Al-Zu'bi et al., 2012). Additionally, reducing setup time results in shorter lead times which will noticeably enhance companies' flexibility to respond to different market trends, deliver finished goods faster, and provide better service levels to customers (Heizer et al., 2013; Tsinopoulos \& Al-Zu'bi, 2012). Moreover, setup time reduction is expected to free valuable manufacturing capacity, improve creativity plant-wide, and assist companies to reach their goals (Al-Zu'bi \& Tsinopoulos, 2012b; Al-Ettayyem \& Al-Zu'bi, 2015).

\subsubsection{Continuous Improvement}

Continuous improvement refers to incremental improvements to existing processes, procedures, products, and services (Imai, 1986). Continuous improvement is a set of activities carried out by employees and aiming at simplifying processes and improving performance (Jha et al., 1996). CI initiatives reflect top management commitment to innovative thinking such as lean production (Abdallah \& Matsui, 2008; Alkalha et al., 2012; Al-Zu'bi \& Khamees, 2014).

The impact of continuous improvement on productivity growth is beyond any doubt (Imai, 1986). Several researchers demonstrated that continuous improvement greatly affects quality, lead time, cost, and delivery of products (Al-Abdallah et al., 2014; Al-Zu'bi et al., 2015a). As such, flexibility performance is expected to be significantly improved. Continuous improvement programs require the involvement of employees from all levels. Small and cross-functional groups might be formulated to increase the effectiveness of those programs. Japanese companies refer to continuous improvement efforts as Kaizen which is considered as a "building block" of lean manufacturing (Imai, 1986). Additionally, Sakakibara et al. (1997) asserted that such improvements represent an overall phenomenon in firms implementing lean production. CI when properly applied may result in substantial improvements. For instance, Pirraglia et al. (2009) reported that CI activities reduce production cycle time and labor by $50 \%$, increase quality and productivity by $50 \%$, reduce inventory cost by $80 \%$, and improve delivery performance, flexibility and profits. Moreover, CI enables companies to continuously meet internal and external customer requirements in an effective and efficient manner (Al-Zu'bi \& Tsinopoulos, 2012a; Al-Zu'bi et al., 2015b). 


\subsubsection{Synchronization of Operations}

Refers to the ability of the plant to balance capacity throughout different processes to ensure smooth flow, bottleneck removal, work-in-process inventory avoidance, and adherence to daily schedules (Flynn et al., 1997; Sakakibara et al., 1997; Abdallah \& Phan, 2007). White et al. (1999) argued that successful synchronization of operations in a lean environment requires reducing the complexities of production processes and physical constraints, simplifying organizational structure, and reducing the number of processes if necessary. Research on lean system pointed to some techniques that enhances synchronization of operations such as small lot size, usage of flexible small machines, meeting daily schedules, and internal coordination and information sharing (Flynn et al., 1997; Matsui, 2004). Additionally, Zhu and Meredith (1995) suggested converting the master schedule from weekly to daily basis to facilitate the adjustment of product mix from one lot to another according to customer requirements. Those activities related to synchronizing processes and operations are expected to greatly affect flexibility performance of manufacturing companies and enable them to respond effectively to customer needs and requirements.

\subsubsection{Pull System}

Pull system is often referred to as a heart of lean manufacturing. It means that products are produced when they are required to be produced not before. In a pull system, parts will move only when they are needed by the next process (Ohno, 1988). Traditional mass production relies on push system whereby parts are pushed along production process based on forecasted demand. Such a situation causes high levels of inventory and overproduction. The principal objective of pull system is to avoid such inventory levels and overproduction (Liker, 2004).

Pull system is expected to improve flexibility performance to a great extent. It depends on customers to signal their needs in terms of quantity, product mix, quality levels, and delivery dates. Downstream customer might be the end customer or the next operator in the production line (Shingo, 1985). As push system is a make-to-order approach, it requires a fast and smooth flow in order to respond to customer needs in a timely manner (Liker, 2004). Notable space savings under the pull system increases productivity and facilitates quick response to customers. Pull system enables manufacturing companies to quickly adjust to changing customer demand resulting in higher flexibility compared to traditional push system.

\subsection{Flexibility Performance}

Flexibility was defined as "the ability to implement changes in the internal operating environment in a timely manner at a reasonable cost in response to changes in market conditions" (Watts et al., 1993). Thus, flexibility can be considered to be a response to environmental uncertainty (Gupta \& Goyal, 1989). Flexibility is multidimensional and includes dimensions such as mix flexibility, changeover flexibility, volume flexibility, rerouting flexibility, and material flexibility (Gerwin, 1993). It enables companies to be responsive to uncertainty in the amount of customer demand and preferences and to adjust volume and mix of output to meet market demand (D'souza \& Williams, 2000; Gerwin, 1993). Such a capability requires the ability to introduce new or customized products (Abdallah \& Matsui, 2009), provide a variety of products (Tsinopoulos \& Al-Zu'bi, 2014), flexibility to change initially planned delivery dates (Abdallah et al., 2009), the ability to modify product mix effectively (Al-Zu'bi et al., 2015), and the rapidity with which companies respond to signals of environment (Zaheer \& Zaheer, 1997). Heizer et al. (2013) pointed to flexibility performance as the ability to develop products on time, deliver products fast, have reliable scheduling, and flexible performance. They further argued that customers will perceive the value of company's flexibility via its ability to match changes in a marketplace in a timely manner while maintaining smooth processes. Womack et al. (1990) described Toyota's operational flexibility as the ability to compete at the same time on delivery performance, quality performance, differentiation, product price, development time, and lead time reduction. Moreover, Zhang and Sharifi (2000) argued that the leanness level of an organization can be assessed through its flexdibility to respond to changes in business environment and market needs. Similarly, Bessant et al. (2003) asserted that flexibility is the key to competitive success and encompasses the ability to respond quickly and flexibly to environmental requirements as well as the ability to respond to emerging challenges with innovative reactions and solutions.

\subsection{Previous Studies on Lean-Performance Relationship}

Many previous studies investigated the effects of lean production on operational and financial performance and reported mainly positive relationships (Shah \& Ward, 2003; Kannan \& Tan, 2005; Jayaram et al., 2008; Hallgren \& Olhager, 2009; Abdallah \& Matsui, 2009; Rahman et al., 2010; Phan et al., 2011; Al-Abdallah et al., 2014). Some studies investigated the effects of lean production on individual operational performance dimensions. For instance, Upton (1995) and Swink et al. (2005) found positive association between lean production and 
flexibility performance. Other researchers reported positive impact of lean production on quality performance (Cua et al., 2001; Kannan \& Tan, 2005; Abdallah \& Matsui, 2007). The effect of lean manufacturing on cost performance was extensively investigated by researchers and there is a consensus that the effect is positive and significant (Fullerton \& McWatters, 2001; Browning \& Heath, 2009; Abdallah \& Matsui, 2009). Also, the association between lean manufacturing and delivery performance was found positive (Fullerton \& McWatters, 2001; Cua et al., 2001; Abdallah \& Matsui, 2007; Abdallah \& Matsui, 2009). Taj and Morosan (2011) found positive effects of lean practices on three performance dimensions of flow, quality, and flexibilty.

On the other hand, Sakakibara et al. (1997) didn't find a significant relationship between lean manufacturing and operational performance. Similar results were reported by Patterson et al. (2004) and Birdi et al. (2008). Callen et al. (2000) found that only some lean practices were significantly related to operational performance. Swink et al. (2005) found that lean practices were not related to cost performance.

\subsection{Theoritical Literature on Lean-Flexibility Relationship}

Womack et al. (1990) argued that lean system represents a radical process innovation that enabled Toyota to be highly flexible in responding to its customers. They further asserted that lean philosophy is not restricted to Japanese companies or automobile plants, but has broad applicability in different countries, cultures, and industries. Lean system allows manufacturing companies to be flexible to the dynamics changes of customer needs and requirements (Holweg, 2005). Additionally, lean system will result in a flexible supply chain for firms offering a variety of products, including innovative and customized products as it enables companies to adjust to customers' fluctuating demand through postponing the final assembly until the actual customer demand becomes known (Lee, 2002; Roh et al., 2014). According to Hay (1988) lean production not only enables companies to improve quality of their products, but also helps them to cut response time to market by as much as 90 percent. He further argued that new or modified products requested by the customer can be developed and deliveried in half the time it currently takes while inventories and capital equipment necessary to do this can be drastically reduced. Such a market oriented lean system increases flexibility and enhances rapid market responses not only to unpredictable customer demand, but also to volatile sources of supply (Roh et al., 2014). Kilpatrick (2003) asserted that lean production enables companies to become more flexible and responsive to market trends as they will be able to deliver products faster and cheaper. Roh et al. (2014) asserted that flexibility increases competitiveness of manufacturing companies in today's uncertain, dynamic, and risky business environment.

The focus of previous empirical studies was mainly on the effect of lean production on operational performance as one overall measure. Even though the literature provided various theoritical arguments on lean-flexibility relationship, there is a need for empirical evidence to highlight this relationship, especially in developing countries. Additionally, this relationship has not been investigated under environmental dynamism.

\subsection{Environmental Dynamism and Lean Production}

Environmental dynamism refers to the rate at which the needs and preferences of customers change (Wijbenga \& Witteloostuijn, 2007). Factors leading to external dynamism include reduced product life cycles and increased product variety (Mitchell et al., 2011), advancements in information technology and e-business, and increased global competition (Abdallah et al., 2014). Azadegan et al. (2013) indicated that lean manufacturing literature lacks studies concerning the effect of environmental dynamism on lean-performance relationship and called for further studies to investigate this research gap.

One stream of research argued that environmental dynamism leads to negative effects on performance due to the difficulty of making accurate forecasts, evaluating changes, developing timely responses, modifying schedules, and increased ambiguity (Azadegan et al., 2013; Patel et al., 2013; Gorman et al., 2009 ). Azadegan et al. (2013) argued that environmental dynamism reduces lean-performance relationship for some reasons such as difficulty of synchronizing operations, increased uncertainty, and less emphases on waste minimization.

Another stream of research asserted that market oriented companies with flexible processes and technology accompanied with close customer relationship will be able not only to cope with the challenges related to environmental dynamism, but also enhance their performance and outperform their competitors (Guar et al., 2011; Qi \& Zhang, 2010). For instance, Vivek and Ravindran (2008) argued that only lean system will enable companies to effectively respond to changing needs and preferences of customers in a highly dynamic environment. They found that environmental uncertainty highly and positively related to lean practices in Indian small manufacturing companies. Zhang et al. (2012) empirically demonstrated that the effect of quality exploration on operational performance was higher under high environmental uncertainty. Their measures of quality exploration constructs reflected indeed lean aspects such as customer focus (exploring customer needs and customer involvement in product development), process management (exploring improvements of processes 
and products), and team work and training (cross-functional cooperation and training on multiple tasks and skills including new ones).

All Previous studies concerning the moderating effect of environmental dynamism on lean-performance relationship that we reviewed considered performance as one overall measure that encompasses aspects of cost, quality, delivery, productivity, and others. This may potentially explain the contrasting results reported by researchers. As we concentrate in this study on flexibility performance, we propose that environmental dynamism will further strengthen the effect of lean practices on flexibility performance. In a stable and predictable environment, the benefits of lean system are more likely to be related to cost and quality aspects, and those benefits may be weakened as environment changes from stable to dynamic.

\section{Framework and Research Hypotheses}

\subsection{Research Framework}

The effects of lean production on performance were investigated in the literature using either lean bundles/groups or individual lean practices. The first approach is appropriate when surveyed manufacturing companies have deep knowledge and experience with the lean philosophy. As the lean system is newly adopted by Jordanian plants, the second approach of examining the effects of individual lean practices on flexibility performance was selected.

The reseach framework is illustrated in Figure 1. The framework reflects the moderating effect of environmental dynamism on the effect of lean practices on flexibility performance.

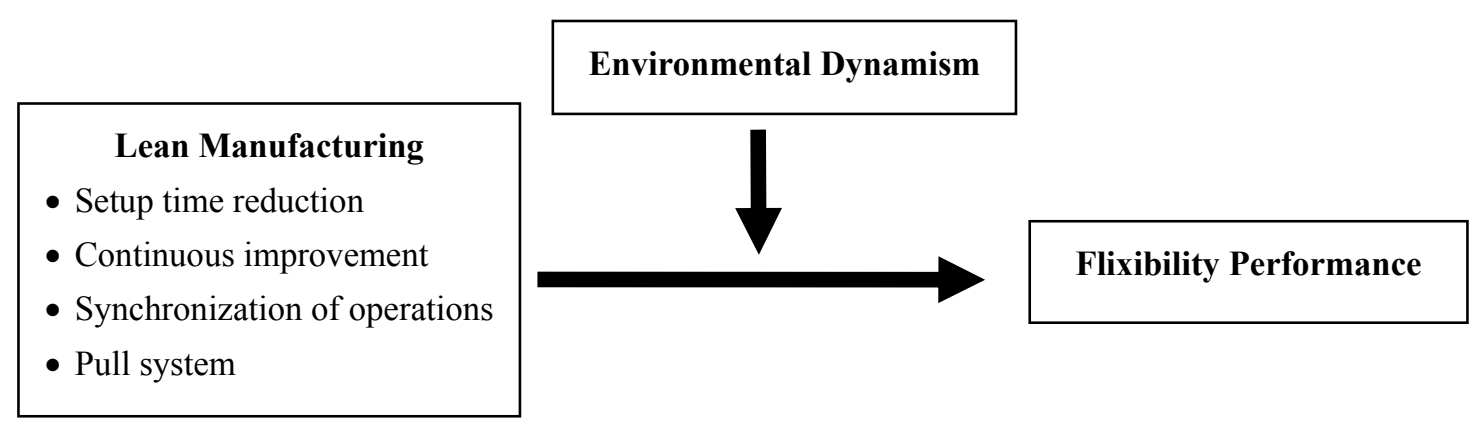

Figure 1. Research framework

\subsection{Research Hypotheses}

Based on our literature review, theoretical background, and the underlying framework, we propose the following hypotheses:

H1a: Setup time reduction will be positively related to flexibility performance

H1b: Environmental dynamism will positively moderate the effect of setup time reduction on flexibility performance

H2a: Continuous improvement will be positively related to flexibility performance

$\mathrm{H} 2 \mathrm{~b}$ : Environmental dynamism will positively moderate the effect of continuous improvement on flexibility performance

H3a: Synchronization of operations will be positively related to flexibility performance

H3b: Environmental dynamism will positively moderate the effect of synchronization of operations on flexibility performance

H4a: Pull system will be positively related to flexibility performance

H4b: Environmental dynamism will positively moderate the effect of pull system on flexibility performance

\subsection{Data Collection}

To test the hypotheses proposed in the previous section, a survey questionnaire method was selected to gather data for this reseach. To ensure content and face validity, the measurement scales were adapted from the literature after conducting an extensive review of the related publications (Lee, 2002; Shah \& Ward, 2003; Kannan \& Tan, 2005; Abdallah \& Phan, 2007; Hallgren \& Olhager, 2009; Abdallah \& Matsui, 2009; Rahman et 
al., 2010; Phan et al., 2011; Nawanir et al., 2013; Al-Abdallah et al., 2014; Roh et al., 2014) . The questionnaire was initially written in English language and then translated to Arabic. Next, the questionnaire was reviewed by three academics to ensure that content and translation were appropriate for the research purpose. Based on the received comments, the questionnaire was revised as needed.

The population for this study included all manufacturing companies in Jordan. We visited two hundred and fifty manufacturing companies to ensure high representation. The unit of analysis was operations or manufacturing managers. All the manufacturing companies were visited personally by the researchers. The companies were selected from different industries which included, machinery, pharmaceutical, electrical, textile/garments, food and chemical. As we initially expected, most targeted managers requested us to leave the questionnaires and to collect them in few days. The process of data collection continued about two months. About $30 \%$ of managers who promised to fill out the questionnaires never did that. We received one hundred and seventy five questionnaires. Eighteen questionnaires were unusable and were excluded from further analysis. The final sample consisted of one hundred and fifty seven representing a response rate of $62.8 \%$. This high response rate is not unexpected because personal visits to manufacturing companies were made personaly by the authors. For instance, Suifan et al. (2015) recieved a response rate of $64.3 \%$ as a result of personal visits to insurance companies in Jordan.

\subsection{Measures}

Measurement scales for our constructs were adapted from the literature. Lean production constructs were adapted from Abdallah and Phan (2007), Abdallah and Matsui (2009), Nawanir et al. (2013). Flexibility performance construct was adopted from Taj and Morosan (2011), while environmental dynamism construct was adopted from Azadegan et al. (2013). Respondents were required to assess their agreement or disagreement with the statements provided in the questionnaire using a five-point Likert scale.

Next, we tested assumptions related to multivariate data analysis regarding linearity and normality. The results revealed that those assumptions were not violated. To test construct validity, Exploratory Factor Analysis (EFA) was carried out with the varimax rotation method. KMO (Kaiser-Meyer-Olkin) test for assessing sampling adequacy was performed as recommended by Hair et al. (2010). The results showed that KMO statistic for all constructs was higher than 0.50 implying the appropriateness of factor analysis. We also conducted Bartlett's test of sphericity to test for homogeneity of variances. The results indicated that Bartlett's test of sphericity statistics were statistically significant $(\mathrm{p}<0.05)$ indicating that we could proceed with factor analysis. Our purpose of performing factor analysis was to ensure that all items within a construct loaded onto one factor with eigenvalue greater than 1 . Only question items with factor loading of at least 0.40 were retained (Hair et al., 2010). Three question items showed a factor loading less than 0.40 and were deleted.

To evaluate the reliability of the constructs, Cronbach's $\alpha$-coefficient was used. Generally, in operations management reseach Cronbach's $\alpha \geq 0.60$ is acceptable (Nunnally, 1978; Shah \& Ward, 2003; Nawanir et al., 2013). All our constructs met the recommended value of $\alpha \geq 0.60$ as shown in Table 1 indicating that the constructs are valid and internally consistent. Additionally, Table 2 below shows the results of EFA for the study constructs along with their references between parenthesis.

Table 1. Summary of statistics of study constructs

\begin{tabular}{lllll}
\hline construct & Mean & $\begin{array}{l}\text { Standard } \\
\text { deviation }\end{array}$ & $\begin{array}{l}\text { No. of question } \\
\text { Items per construct }\end{array}$ & $\begin{array}{l}\text { Alpha } \\
\text { coefficient }\end{array}$ \\
\hline 1. Setup time reduction & 3.36 & 0.741 & 5 & 0.726 \\
2. Continuous improvement & 3.86 & 0.829 & 5 & 0.742 \\
3. Synchronization of operations & 3.68 & 0.779 & 4 & 0.711 \\
4. Pull system & 3.12 & 0.983 & 5 & 0.687 \\
5. Flexibility performance & 3.81 & 0.782 & 4 & 0.709 \\
6. Environmental dynamism & 3.27 & 0.649 & 6 & 0.664 \\
\hline
\end{tabular}


Table 2. Exploratory factor analysis (varimax rotation)

\begin{tabular}{|c|c|c|c|}
\hline variables & $\begin{array}{l}\text { Factor } \\
\text { loading }\end{array}$ & Eigenvalue & $\begin{array}{l}\text { Percentage } \\
\text { of variance }\end{array}$ \\
\hline Setup time reduction (Abdallah \& Phan, 2007) & & 3.387 & $59.64 \%$ \\
\hline We are aggressively working to lower setup times in our plant. & .701 & & \\
\hline $\begin{array}{l}\text { We have converted most of our setup time to external time, while } \\
\text { the machine is running. We have low setup times of equipment in }\end{array}$ & .592 & & \\
\hline Our crews practice setups, in order to reduce the time required. & .773 & & \\
\hline Our workers are trained to reduce setup time & .814 & & \\
\hline Our setup times seem hopelessly long (R) & .550 & & \\
\hline Continuous improvement (Abdallah \& Matsui, 2009) & & 2.378 & $57.00 \%$ \\
\hline $\begin{array}{l}\text { We strive to continually improve all aspects of products and } \\
\text { processes, rather than taking a static approach. }\end{array}$ & .747 & & \\
\hline $\begin{array}{l}\text { If we aren't constantly improving and learning, our performance } \\
\text { will suffer in the long term. }\end{array}$ & .745 & & \\
\hline $\begin{array}{l}\text { Continuous improvement makes our performance a moving } \\
\text { target, which is difficult to attack. }\end{array}$ & .688 & & \\
\hline There is always room for more incremental process improvement. & .773 & & \\
\hline $\begin{array}{l}\text { Our organization is not a static entity, but engages in dynamically } \\
\text { changing itself to better serve its customers. }\end{array}$ & .711 & & \\
\hline Synchronization of operations (Abdallah \& Phan, 2007) & & 3.387 & $56.45 \%$ \\
\hline Capacities are balanced in our supply network. & .747 & & \\
\hline $\begin{array}{l}\text { Our manufacturing capacity is balanced throughout the entire } \\
\text { manufacturing process. }\end{array}$ & .745 & & \\
\hline We have large inventories between different operations (R). & .688 & & \\
\hline Our suppliers do not use large inventories to supply us & .773 & & \\
\hline Pull system (Nawanir et al., 2013) & & 2.252 & $45.03 \%$ \\
\hline $\begin{array}{l}\text { We use a production system in which items are produced only } \\
\text { when called for by the users of those items. }\end{array}$ & .792 & & \\
\hline $\begin{array}{l}\text { Production is performed based on the shipment of goods from } \\
\text { previous workstation. }\end{array}$ & 648 & & \\
\hline $\begin{array}{l}\text { We use a production system in which items are produced only in } \\
\text { necessary quantities, no more and no less. }\end{array}$ & .795 & & \\
\hline $\begin{array}{l}\text { To authorize the order, we use a supplier kanban that rotates } \\
\text { between factory and suppliers }\end{array}$ & .816 & & \\
\hline $\begin{array}{l}\text { Production at a workstation is performed based on the current } \\
\text { demand of the subsequent workstation. }\end{array}$ & .586 & & \\
\hline Flexibility performance (Taj \& Morosan, 2011) & & 2.563 & $42.71 \%$ \\
\hline Product-mix flexibility & .666 & & \\
\hline Production volume flexibility & 696 & & \\
\hline On-time delivery & 602 & & \\
\hline Plant uptime & .754 & & \\
\hline Environmental dynamism (Azadegan et al., 2013) & & 2.132 & $42.63 \%$ \\
\hline Major changes in the modes of production provision & .738 & & \\
\hline A high rate of innovation & .513 & & \\
\hline Major changes in consumer demographics & .471 & & \\
\hline Frequent and major changes in government regulations & .764 & & \\
\hline An increasing amount of spending on research and development & .773 & & \\
\hline Frequent and major changes in the number of competitors & .593 & & \\
\hline
\end{tabular}




\section{Results}

We used hierarchical regression analysis to test our hypotheses. A common problem in multiple regression analysis is multicollinearity which usually occurs when independent variables are highly correlated. Such a situation increases shared variance and reduces unique variance of individual independent variables resulting in incorrect regression coefficients and statistical significance (Hair et al., 2010). Two widely used measures for assessing multicollinearity are tolerance and Variance Inflation Factor (VIF). Small tolerance values and large VIF values indicate the existence of multicollinearity. Even though a cutoff VIF value of 10 is accepted by some researchers, Hair et al. (2010) asserted that such a common cutoff threshold still allow for high collinearity. They recommended researchers to decide the acceptable degree of collinearity. We followed the conservative cutoff VIF values of 2.5 proposed by Allison (1999). The VIF values of the independent variables in our regression models ranged between 1.033-2.023 indicating that multicollinearity was not a concern in our models.

The results of hierarchical regression analysis are reported in Table 2. According to Hair et al. (2010), number of observations is preferred to be 15 times the number of variables in order to maximize degrees of freedom and improve generalizability of the results, therefore our sample size of 157 was appropriate for multiple regression analysis. We used three models to test our hypotheses. In the first model, lean practices were entered in order to test their effects on flexibility performance. In the second model, we added environmental dynamism, the moderator, to lean practices. In the third model, we added the interaction effects of each lean practice with environmental dynamism in order to test the interaction effects. The addition of the interaction effects resulted in high multicollinearity, therefore, we centered the independent variables and the moderating variable at the mean and recreated the two-way interaction terms. The VIF diagnostics showed no multicollinearity problems and the highest VIF value was 2.023 .

The results of the first model showed that lean practices collectively significantly contributed to the explanation of the variance in the level of flexibility performance. Coefficient of determination, $\mathrm{R}^{2}$, indicated that $27.4 \%$ of the variance in flexibility performance explained by the lean practices, and generally $\mathrm{R}^{2}$ can be regarded as a measure of a goodness of fit of the multiple regression model (Hair et al., 2010). The adjusted $\mathrm{R}^{2}$ of 0.249 in the first regression model indicated that the $\mathrm{R}^{2}$ was slightly decreased due to the number of independent variables and sample size. The F-value of 10.775 is highly significant indicating that there was a significant positive effect of lean practices on flexibility performance. To test the individual effect of each lean practice on flexibility performance, standardized beta weights (coefficients) were reported with their corresponding significance. Beta coefficients indicate the rate of change in flexibility performance (the dependent variable) resulting from an increase of one standard deviation in the corresponding lean practice (independent variable). The results in Table 3 showed that all lean practices were positively and significantly related to flexibility performance; therefore, hypotheses H1a, H2a, H3a, and H4a were accepted.

The addition of environmental dynamism in the second regression model did not result in significant change of the variance in flexibility performance. In the third model, the addition of interaction effects resulted in an additional significant change in $\mathrm{R}^{2}(9.6 \%, p<0.01)$ indicating that the predictive power of the regression model increased. The interaction results showed that environmental dynamism significantly and positively $(p<0.01)$ affected the relationship between synchronization of operations and flexibility performance. The effects of the other three interactions were insignificant. Hypothesis H3b was accepted while hypotheses H1b, H2b, and H4b were rejected. 
Table 3. Hierarchical regression analysis of flexibility performance

\begin{tabular}{llll}
\hline Variables & Model 1 & Model 2 & Model 3 \\
\hline (Constant) & $3.337^{* *}$ & $3.335^{* *}$ & $3.355^{* *}$ \\
Independent variables & & & \\
Setup time reduction & $0.196^{*}$ & $0.194^{*}$ & 0.155 \\
Continuous improvement & $0.315^{* *}$ & $0.316^{* *}$ & $0.327^{*}$ \\
Synchrinization of operations & $0.375^{* *}$ & $0.377^{* *}$ & $0.234^{*}$ \\
Pull system & $0.316^{* *}$ & $0.312^{* *}$ & $0.220^{*}$ \\
Moderating variable & & & \\
Environmental dynamism (ED) & & -0.027 & 0.067 \\
Interaction effects & & & \\
Setup time reduction X ED & & & -0.033 \\
Continuous improvement X ED & & & -0.111 \\
Synchrinization of operations X ED & & & $0.315^{* *}$ \\
Pull system X ED & & 0.275 & 0.135 \\
$\mathrm{R}^{2}$ & 0.274 & 0.243 & 0.371 \\
Adj. $\mathrm{R}^{2}$ & 0.249 & 0.001 & 0.319 \\
$\mathrm{R}^{2}$ change & & $8.575^{* *}$ & 0.096 \\
F & $10.775^{* *}$ & 0.109 & $7.143^{* *}$ \\
F change & & & $4.156^{* *}$ \\
\hline$*$ P & & &
\end{tabular}

$* \mathrm{P} \leq 0.05 ; * * \mathrm{P} \leq 0.01$

\section{Discussion and Conclusions}

This study investigated the impact of lean production on flexibility performance in Jordanian manufctuing companies. The moderating effect of environmental dynamism on this relationship was examined. We focused on core and internal lean practices which included setup time reduction, continuous improvement, synchronization of operations, and pull system.

The results provided empirical evidence of the positive and significant effect of lean production on flexibility performance in a developing country. This consisted with other studies conducted in developing countries (Nawanir et al., 2013; Agus \& Hajinoor, 2012; Rahman et al., 2010; Wong et al., 2009). The implementation level of lean practices in Jordan was found to be above average. This result should not be seen surprising. Pressures on Jordanian manufacturers during the last decade seemed to yield operational improvements. Severe global competition accompanied with strict requirements from the European Union, USA, and other global markets for Jordanian exporters to enter those markets have forced many companies to adopt innovative operational practices in order to comply with the imposed standards.

All lean practices proved to positively and significantly related to flexibility performance. Synchronization of operations showed the highest level of significance. The tendency of several recent studies on lean production is to surprisingly neglect this basic practice (Chavez et al., 2015; Bortolotti et al., 2015; Dora et al., 2014; Nawanir et al., 2013; Agus \& Hajinoor, 2012). Our finding re-directs the attention of lean researchers and practitionrs back to the origins of lean philosophy where synchronized operations were regarded as the pillar of the lean system. Synchronized operations at all aspects of production ensure smooth flow of products across the entire value chain (Womack \& Jones, 2003). Flow disruption due to poorly synchronized operations will increase waste and obstruct the whole system.

Pull system and continuous improvement were also highly related to flexibility performance. Pull system depicts an overall commitment and readiness to the lean philosophy whereby materials are only released to produce what customers demand. This is the ultimate goal of flexible and responsive lean process. Continuous and incremental improvements proved to highly enhance flexibility performance. The main objective of continuous improvement is to eliminate barriers to the lean system so that to improve customer responsiveness and 
satisfaction. To have a successful continuous improvement strategy, companies have to continually re-evaluate the targets, priorities, and measures of the intended improvements so that to ensure an effective response to market requirements (Agus \& Hajinoor, 2012). Our result consisted with the results of Agus and Hajinoor (2012), Chavez et al. (2015), and Bortolotti et al. (2015), among the others, who empirically demonstrated the importance of continuous improvement in a flexible lean environment. It should be mentioned that many researchers did not consider continuous improvement as a lean practice in their studies which led to missing an important key aspect of the system (Rahman et al., 2010; Dora et al., 2014; Khanchanapong et al., 2014). Setup time reduction was also significantly related to flexibility performance, but evidently with less levels of significance than the other practices.

Our study highlighted how environmental dynamism affects lean-flexibility relationship. The results of the interaction terms revealed that the effect of synchronization of operations on flexibility performance increased with higher levels of environmental dynamism. Accurate and timely arrangements for synchronization of operations and processes assist to confront uncertain and dynamic environment and adjust effectively to changing customer requirements. This effect of synchronized operations further enhances flexibility performance when environmental dynamism is high. This result is inconsistent with the findings of Azadegan et al. (2013) who found negative moderating effect of environmental dynamism on the relationship between lean operations and performance. One possible explanation for such inconsistency, knowing that we adapted their construct of environmental dynamism, is that they used financial measure of performance while we used internal business measure.

The interaction effects between other lean practices and environmental dynamism were insignificant. This suggests that flexibility benefits of those practices will not change in a volatile environment. The effect of environmental factors on lean-performance relationship has been a notable controversial issue in the literature. We contributed to the literature in this regard by examing the interaction effect of each individual lean practice with environmental dynamism.

Our study has some limitations that should be considered alongside with the interpretation of the reported findings, and which may suggest directions for future research. First, we focused on internal within plant lean practices. External lean practices may also have enhanced flexibility performance. Future research should extend our model to include internal and external lean practices. Second, we included only one moderating variable in our model. Several other moderating variables may affect the proposed relationship. Future research may investigate the moderating effect of other variables such as technological turbulence, competitive intensity, and environmental complexity. Third, We focused only on flexibility performance. Future research has an interesting avenue to extend our model to include other performance aspects such as cost, quality, and delivery.

\section{References}

Abdallah, A., \& Matsui, Y. (2007a). Just In Time Production and Total Productive Maintenance: Their Relationship and Impact on JIT and Competitive Performances. In Proceedings of the 9th International Decision Sciences Institute Conference. Bangkok, Thailand. http://dx.doi.org/10.13140/2.1.4925.9846

Abdallah, A., \& Matsui, Y. (2008). Customer Involvement, Modularization of Products, and Mass Customization: Their Relationship and Impact on Value to Customer and Competitiveness. In Proceedings of the Third World Conference on Production and Operations Management. Tokyo, Japan. http://dx.doi.org/ $10.13140 / 2.1 .2632 .2246$

Abdallah, A., \& Matsui, Y. (2009). The Impact of Lean Practices on Mass Customization and Competitive Performance of Mass-Customizing plants. In Proceedings of the 20th Annual Production and Operations Management Society (POMS) Conference. Orlando, USA. http://dx.doi.org/10.13140/2.1.2445.8563

Abdallah, A., \& Phan, C. A. (2007). The Relationship between Just-In-Time Production and Human Resource Management, and Their Impact on Competitive Performance. Yokohama Business Review, 28(2), 27-57.

Abdallah, A. B. (2013). The Influence of "Soft" and "Hard" Total Quality Management (TQM) Practices on Total Productive Maintenance (TPM) in Jordanian Manufacturing Companies. International Journal of Business and Management, 8(21), 1-13. http://dx.doi.org/10.5539/ijbm.v8n21p1

Abdallah, A. B., Obeidat, B. Y., \& Aqqad, N. O. (2014). The Impact of Supply Chain Management Practices on Supply Chain Performance in Jordan: The Moderating Effect of Competitive Intensity. International Business Research, 7(3), 13-27. http://dx.doi.org/10.5539/ibr.v7n3p13

Abdallah, A. B., Phan, A. C., \& Matsui, Y. (2009). In Investigating the Relationship between Strategic Manufacturing Goals and Mass Customization. Proceedings of the 16th International Annual European 
Operations Management Association (EurOMA). Goteborg, Sweden. http://dx.doi.org/10.13140/ 2.1.4404.8160

Abdallah, A. B., \& Matsui, Y. (2007b). The relationship between JIT production and manufacturing strategy and their impact on JIT performance. In Proceedings of the 18th Annual Production and Operations Management Society (POMS) Conference. Dallas, USA.

Ahmad, S., Schroeder, R., \& Sinha, K. (2003). The role of infrastructure practices in the effectiveness of JIT practices: Implications for plant competitiveness. Journal of Engineering and Technology Management, 20(3), 161-191. http://dx.doi.org/10.1016/S0923-4748(03)00017-1

Agus, A., \& Hajinoor, M. (2012). Lean production supply chain management as driver towards enhancing product quality and business performance: Case study of manufacturing companies in Malaysia. International Journal of Quality and Reliability Management, 29(1), 92-121. http://dx.doi.org/10.1108/02656711211190891

Al Hasan, R., \& Al-Zu'bi, Z. M. F. (2014). Evaluating the Relationships between Lean Manufacturing Dimensions and Radical Product Innovation in the Jordanian Pharmaceutical Sector. European Scientific Journal, 10(1), 230-258.

Al-Abdallah, G. M., Abdallah, A. B., \& Bany Hamdan, K. (2014). The Impact of Supplier Relationship Management on Competitive Performance of Manufacturing Firms. International Journal of Business and Management, 9(2), 192-202. http://dx.doi.org/10.5539/ijbm.v9n2p192

Albert, M. (2004). Setup Reduction: At the Heart of Lean Manufacturing. Modern Machine Shop. Retrieved from http://www.mmsonline.com/articles/setup-reduction-at-the-heart-of-lean-manufacturing

Al-Ettayyem, R., \& Al-Zu'bi, Z. M. F. (2015). Investigating the Effect of Total Quality Management Practices on Organizational Performance in the Jordanian Banking Sector. International Business Research, 8(3), 79-90. http://dx.doi.org/10.5539/ibr.v8n3p79

Alkalha, Z., Al-Zu'bi, Z. M. F., Al-Dmour, H., Alshurideh, M., \& Masa'deh, R. (2012). Investigating the Effect of Human Resource Policies on Organizational Performance: An Empirical Study on Commercial Banks Operating in Jordan. European Journal of Economics, Finance and Administrative Sciences, 1, 94-102.

Allison, P. D. (1999). Multiple Regression: A Primer. Thousand Oaks, Pine Forge Press, CA.

Al-Zu'bi, Z. M. F., \& Khamees, B. A. (2014). Activity-Based Costing vs. Theory of Constraints: An Empirical Study into Their Effect on the Cost Performances of NPD Initiatives. International Journal of Economics and Finance, 6(1), 157-165. http://dx.doi.org/10.5539/ijef.v6n12p157

Al-Zu'bi, Z. M. F., Alshurideh, M., Abuhamed, A., \& Ghannajeh, A. M. (2015a). A Qualitative Analysis of Product Innovation in Jordan's Pharmaceutical Sector. European Science Journal, 11(4), 474-503.

Al-Zu'bi, Z. M. F. (2010). Collaboration in Mass Customisation: Exploring the impacts of suppliers and lead users (1st ed.). VDM Verlag, Germany.

Al-Zu'bi, Z. M. F., \& Tsinopoulos, C. (2012a). Suppliers versus Lead Users: Examining Their Relative Impact on Product Variety. Journal of Product Innovation Management, 29(4), 667-680. http://dx.doi.org/10.1111/j.1540-5885.2012.00932.x

Al-Zu'bi, Z. M. F., \& Tsinopoulos, C. (2012b). An Outsourcing Model for Lead Users: An Empirical $\begin{array}{lllll}\text { Investigation. Production Planning and } & \text { Control, } & \text { 24(4/5), } & \text { 1-10. }\end{array}$ http://dx.doi.org/10.1080/09537287.2011.648485

Al-Zu'bi, Z. M. F., Dahiyat, S. E., Warrad, T., Shannak, R. O., \& Masa'deh, R. M. (2012). Investigating the Effect of Foreign Direct Investment Technology Transfer on Mass Customization Capability in Jordan's Manufacturing Sector. International Research Journal of Finance and Economics, 94(1), 79-90.

Al-Zu'bi, Z. M. F., Al-Lozi, M., Dahiyat, S., Alshurideh, M., \& Al Majali, A. (2012). Examining the Effect of Quality Management Practices on Product Variety. European Journal of Economics, Finance and Administrative Sciences, 1, 1-19.

Al-Zu'bi, Z. M. F., Tarawneh, E., Abdallah, A. B., \& Fidawi, M. (2015). Investigating Supply Chain Integration Effects on Environmental Performance in the Jordanian Food Industry. American Journal of Operations Research, 5(4), 247-257. http://dx.doi.org/10.4236/ajor.2015.54019

Atkinson, P. (2004). Creating and Implementing Lean Strategies. Management Services, 48(2), 18-21. 
Azadegan, A., Patel, P., Zangoueinezhad, A., \& Linderman, K. (2013). The effect of environmental complexity and environmental dynamism on lean practices. Journal of Operations Management, 31(4), 193-212. http://dx.doi.org/10.1016/j.jom.2013.03.002

Bessant, J., Kaplinsky, R., \& Lamming, R. (2003). Putting supply chain learning into practice. International Journal of Operations \& Production Management, 23(2), 167-184. http://dx.doi.org/10.1108/01443570310458438

Birdi, K., Clegg, C., Patterson, M., Robinson, A., Stride, C., Wall, T., \& Wood, S. (2008). The impact of human resource and operational management practices on company productivity: A longitudinal study. Personnel Psychology, 61(3), 467-501. http://dx.doi.org/10.1111/j.1744-6570.2008.00136.x

Bortolotti, T., Boscari, S., \& Danese, P. (2015). Successful lean implementation: Organizational culture and soft lean practices. International Journal of Production Economics, 160(1), 182-201. http://dx.doi.org/10.1016/j.ijpe.2014.10.013

Browning, T., \& Heath, R. (2009). Reconceptualizing the effects of lean on production costs with evidence from the F-22 program. Journal of Operations Management, 27(1), 23-44. http://dx.doi.org/10.1016/j.jom.2008.03.009

Callen, J., Fader, C., \& Krisky, I. (2000). Just-in-time: A cross-sectional plant analysis. International Journal of Production Economics, 63(3), 277-301. http://dx.doi.org/10.1016/S0925-5273(99)00025-0

Chavez, R., Yu, W., Jacobs, M., Fynes, B., Wiengarten, F., \& Lecuna, A. (2015). Internal lean practices and performance: The role of technological turbulence. International Journal of Production Economics, 160, 157-171. http://dx.doi.org/10.1016/j.ijpe.2014.10.005

Cost, F., \& Rothenberg, S. (2004). Lean manufacturing in small and medium sized printers. RIT Printing Industry Center, Rochester, NY.

Cua, K. O., McKone, K. E., \& Schroeder, R. (2001). Purchasing and supply management relationships between implementation of TQM, JIT, and TPM and manufacturing performance. Journal of Operations Management, 19(6), 675-694. http://dx.doi.org/10.1016/S0272-6963(01)00066-3

Danese, P., Romano, P., \& Bortolotti, T. (2012). JIT production, JIT supply and performance: Investigating the moderating effects. Industrial Management and Data Systems, 112(3), 441-465. http://dx.doi.org/10.1108/02635571211210068

Detty, R., \& Yingling, J. (2000). Quantifying benefits of conversion to lean manufacturing with discrete event simulation: A case study. International Journal of Production Research, 38(2), 429-445. http://dx.doi.org/10.1080/002075400189509

Dora, M., Goubergen, D., Kumar, M., Molnar, A., \& Gellynck, X. (2014). Application of lean practices in small and medium-sized food enterprises. British Food Journal, 116(1), 125-141. http://dx.doi.org/10.1108/BFJ-05-2012-0107

Flynn, B., Schroeder, R., Flynn, E., Sakakibara, S., \& Bates, K. (1997). World-class manufacturing project: Overview and selected results. International Journal of Operations \& Production Management, 17(5), 671-685. http://dx.doi.org/10.1108/01443579710175592

Fullerton, R. \& McWatters, C. (2001). The production performance benefits from JIT implementation. Journal of Operations Management, 19(1), 81-96. http://dx.doi.org/10.1016/S0272-6963(00)00051-6

Gaur, S., Vasudevan, H., \& Gaur, A. (2011). Market orientation and manufacturing performance of Indian SMEs. European Journal of Marketing, 45(7/8), 1172-1193. http://dx.doi.org/10.1108/03090561111137660

Gorman, M., Hoff, J., \& Kinion, R. (2009). ASP, the art and science of practice: tales from the front: Case studies indicate the potential pitfalls of misapplication of lean improvement programs. Interfaces, 39(6), 540-548. http://dx.doi.org/10.1287/inte.1090.0464

Hallgren, M., \& Olhager, J. (2009). Lean and agile manufacturing: Internal and external drivers and performance outcomes. Int.J.Operat.Prod.Manag, 29(10), 976-999. http://dx.doi.org/10.1108/01443570910993456

Hair, J. F., Black, W. C., Babin, B. J., \& Anderson, R. E. (2010). Multivariate Data Analysis: A Global Perspective. Pearson Education, Upper Saddle River, NJ.

Hay, E. J. (1988). The just-in-time breakthrough. New York: Wiley.

Heizer, J., Render, P., \& Zu'bi, Z. (2013). Operation Management (Arab World Edition). Pearson Education LTD, 
England.

Holweg, M. (2005). An investigation into supplier responsiveness. International Journal of Logistics Management, 16(1), 96-119. http://dx.doi.org/10.1108/09574090510617376

Imai, M. (1986). Kaizen-The key to Japan's competitive success. McGraw-Hill, New York.

Jain, R., \& Lyons, A. (2009). The implementation of lean manufacturing in the UK food and drink industry. Int. J. Services and Operations Management, 5(4), 548-573. http://dx.doi.org/10.1504/IJSOM.2009.024584

Jayaram, J., Vickery, S., \& Droge, C. (2008). Relationship building, lean strategy and firm performance: An exploratory study in the automotive supplier industry. Int.J. Prod. Res, 46(20), 5633-5649. http://dx.doi.org/10.1080/00207540701429942

Jha, S., Noori, H., \& Michela, J. L. (1996). The Dynamics of Continuous Improvement: Aligning Organisational Attributes and Activities for Quality and Productivity. International Journal of Quality Science, 1(1), 19-47. http://dx.doi.org/10.1108/13598539610117975

Kannan, V., \& Tan, K. (2005). Just in time, total quality management, and supply chain management: Understanding their linkages and impact on business performance. Omega, 33(2), 153-162. http://dx.doi.org/10.1016/j.omega.2004.03.012

Khanchanapong, T., Prajogo, D., Sohal, A., Cooper, B., Yeung, A., \& Cheng, T. (2014). The unique and complementary effects of manufacturing technologies and lean practices on manufacturing operational performance. International Journal of Production Economics, 153(1), 191-203. http://dx.doi.org/10.1016/j.ijpe.2014.02.021

Kilpatrick, J. (2003). Lean Principles. Utah Manufacturing Extension Partnership.

Lee, H. (2002). Aligning supply chain strategies with product uncertainties. California Management review, 44(3), 105-119. http://dx.doi.org/10.2307/41166135

Liker, J. (2004). The Toyota way: 14 management principles from the World's greatest manufacturer. McGraw-Hill, New York.

Mackelprang, A., \& Nair, A. (2010). Relationship between just-in-time manufacturing practices and performance: A meta-analytic investigation. Journal of Operations Management, 28(4), $283-302$. http://dx.doi.org/10.1016/j.jom.2009.10.002

Matsui, Y. (2004). An empirical analysis of just-in-time production in Japanese manufacturing companies. Proceedings of 13th International Symposium in Inventory Research. Budapest, Hungary.

Mitchell, J., Shepherd, D., \& Sharfman, M. (2011). Erratic strategic decisions: Managers are inconsistent in strategic decision making. Strategic Management Journal, 32(7), 683-704. http://dx.doi.org/10.1002/smj.905

Nunnally, J. (1978). Psychometric Theory (2nd ed.). McGraw-Hill, NY.

Nawanir, G., Teong, L. K., \& Othman, S. N. (2013). Impact of Lean practices on operations performance and business performance: Some evidence from Indonesian manufacturing companies. Journal of Manufacturing Technology Management, 24(7), 1019-1050. http://dx.doi.org/10.1108/JMTM-03-2012-0027

Ohno, T. (1988). Toyota Production System. Productivity Press, Portland, OR.

Papadopoulou, T., \& Ozbayrak, M. (2005). Leanness: Experiences from the Journey to Date. Journal of Manufacturing Technology Management, 16(7), 784-807. http://dx.doi.org/10.1108/17410380510626196

Patel, P., Azadegan, A., \& Ellram, L. (2013). The effects of strategic and structural supply chain orientation on operational and customer-focused performance. Decision Sciences Journal, 44(4), 713-753. http://dx.doi.org/10.1111/deci.12034

Patterson, M., West, M., \& Wall, T. (2004). Integrated manufacturing, empowerment and company performance. Journal of Organizational Behavior, 25(5), 641-665. http://dx.doi.org/10.1002/job.261

Phan, A. C., Abdallah, A. B., \& Matsui, Y. (2011). Quality Management Practices and Competitive Performance: Empirical Evidence from Japanese Manufacturing Companies. International Journal of Production Economics, 133(2), 518-529. http://dx.doi.org/10.1016/j.ijpe.2011.01.024

Phan, A., \& Matsui, Y. (2006). JIT Practices and Competitive Performance: Empirical Evidence from Japan. Proceedings of the 17th Annual Conference of Production and Operations Management Society. Boston, 
USA.

Pirraglia, A., Saloni, D., \& Dyk, V. (2009). Status of lean manufacturing implementation on secondary wood industries including residential, cabinet, millwork, and panel markets. BioResources, 4(4), 1341-1358.

Qi, Y., \& Zhang, M. (2010). The impact of manufacturing strategy on mass customization: Moderating effect of environmental uncertainty. International Journal of Decision Science, 1(2), 113-133.

Rahman, S., Laosirihongthong, T., \& Sohal, A. (2010). Impact of lean strategy on operational performance: A study of Thai manufacturing companies. Journal of Manufacturing Technology Management, 21(7), 839-852. http://dx.doi.org/10.1108/17410381011077946

Roh, J., Hong, P., \& Min, H. (2014). Implementation of a responsive supply chain strategy in global complexity: The case of manufacturing firms. International Journal of Production Economics, 147(1), 198-210. http://dx.doi.org/10.1016/j.ijpe.2013.04.013

Sakakibara, S., Flynn, B., Schroeder, R., \& Morris, W. (1997). The impact of just-in-time manufacturing and its infrastructure on manufacturing performance. Management Science, 43(9), 1246-1257. http://dx.doi.org/10.1287/mnsc.43.9.1246

Sanchez, A., \& Perez, M. (2001). Lean indicators and manufacturing strategies. International Journal of Operations and Production $\quad$ Management, 21(11), http://dx.doi.org/10.1108/01443570110407436

Shah, R., \& Ward, P. (2003). Lean manufacturing: Context, practice bundles, and performance. Journal of Operations Management, 21(2), 129-149. http://dx.doi.org/10.1016/S0272-6963(02)00108-0

Shah, R., \& Ward, P. (2007). Defining and developing measures of lean production. Journal of Operations Management, 24(4), 785-805. http://dx.doi.org/10.1016/j.jom.2007.01.019

Shingo, S. (1985). A revolution in manufacturing, the SMED system. Productivity Press, University Park, IL.

Suifan, T. S., Abdallah, A. B., \& Sweis, R. J. (2015). The Effect of a Manager's Emotional Intelligence on Employees Work Outcomes in the Insurance Industry in Jordan. International Business Research, 8(9), 67-82. http://dx.doi.org/10.5539/ibr.v8n9p67

Swink, M., Narasimhan, R., \& Kim, S. (2005). Manufacturing practices and strategy integration: Effects on cost efficiency, flexibility, and market-based performance. Decision Sciences, 36(3), 427-457. http://dx.doi.org/10.1111/j.1540-5414.2005.00079.x

Taj, S., \& Morosan, C. (2011). The impact of Lean operations on the Chinese manufacturing performance. Journal of Manufacturing Technology Management, 2223-240. http://dx.doi.org/10.1108/17410381111102234.

Tsinopoulos, C., \& Al-Zu'bi, Z. M. F. (2012). Clockspeed Effectiveness of Lead Users and Product Experts. International Journal of Operations \& Production Management, 32(2), 1097-1118. http://dx.doi.org/10.1108/01443571211265710

Tsinopoulos, C., \& Al-Zu'bi, Z. M. F. (2014). Lead Users, Suppliers, and Experts: The Exploration and Exploitation Trade-off in Product Development. International Journal of Technology Marketing, 9(2), 6-20. http://dx.doi.org/10.1504/IJTMKT.2014.058080

Upton, D. M. (1995). Flexibility as process mobility: The management of plant capabilities for quick response manufacturing. Journal of Operations Management, $205-224$. http://dx.doi.org/10.1016/0272-6963(95)00004-C

Vivek, N., \& Ravindran, S. (2012). An Empirical Study on the Impact of Environmental Uncertainty on the Lean Practices of Small Manufacturing Firms: A Supply Chain Perspective. Journal of Contemporary Research in Management, 3(3), 113-124.

White, R., Pearson, J., \& Wilson J. (1999). JIT manufacturing: A survey of Implementation in small and large U.S. manufacturers. Management science, 45(1), 1-15. http://dx.doi.org/10.1287/mnsc.45.1.1

Wijbenga, F., \& Witteloostuijn, A. (2007). Entrepreneurial locus of control and competitive strategies: The moderating effect of environmental dynamism. Journal of Economic Psychology, 28(5), 566-589. http://dx.doi.org/10.1016/j.joep.2007.04.003

Womack, J., \& Jones, D. (2003). Lean Thinking: Banish Waste and Create Wealth for Your Corporation (2nd ed.). Simon and Schuster, New York. 
Womack, J. P., Jones, D. T., \& Roos, D. (1990). The Machine that Changed the World. Macmillan, New York, NY.

Wong, Y. C., Wong, K. Y., \& Ali, A. (2009). A study on lean manufacturing implementation in the Malaysian electrical and electronics industry. European Journal of Scientific Research, 38(4), 521-535.

Worley, J., \& Doolen, T. (2006). The role of communication and management support in a lean manufacturing implementation. Management Decision, 44(2), 228-245. http://dx.doi.org/10.1108/00251740610650210

Zaheer, A., \& Zaheer, S. (1997). Catching the wave: Alertness, responsiveness, and market influence in global electronic networks. Management science, 43(11), 1493-1509. http://dx.doi.org/10.1287/mnsc.43.11.1493

Zhang, Z., \& Sharifi, H. (2000). A methodology for achieving agility in manufacturing organizations. International Journal of Operations \& Production Management, 20(4), 496-513. http://dx.doi.org/10.1108/01443570010314818

Zhang, D., Linderman, K., \& Schroeder, G. (2012). The Moderating Role of Contextual Factors on Quality Management Practices. Journal of Operations Management, 30(1), 12-23. http://dx.doi.org/10.1016/j.jom.2011.05.001

Zhu, Z., \& Meredith, P. (1995). Defining critical elements in JIT implementation: A survey. Industrial Management \& Data Systems, 95(8), 21-28. http://dx.doi.org/10.1108/02635579420063252

\section{Copyrights}

Copyright for this article is retained by the author(s), with first publication rights granted to the journal.

This is an open-access article distributed under the terms and conditions of the Creative Commons Attribution license (http://creativecommons.org/licenses/by/3.0/). 